\title{
ELECTIONS AS A POLITICAL TOOL OF REGIONAL ELITES: THE CASE OF THE KABARDIN-BALKAR REPUBLIC
}

\author{
A.A. TUMOV \\ FSBSE «Federal Scientific Center \\ 'Kabardin-Balkar Scientific Center of the Russian Academy of Sciences'» \\ 360000, KBR, Nalchik, Pushkin street, 18 \\ E-mail: tumovasker@gmail.com
}

\begin{abstract}
The post-Soviet Russian state formation, which has been considered as an example of "failed transition to democracy", provides us with a large room for exploring the role of unfair elections in the statebuilding process and enables to delve into the subnational-level elections in order to reveal their covert and non-obvious functions. Indeed, given that elections per se are a part of a broader picture, it is vitally important to comprehend their veiled nature in order to explain their context, results, outcomes, and incentives of the key contributors. The focus of the current research is limited to the Kabardin-Balkar Republic, Russian ethnic enclave located in the North Caucasus. The paper deals with the national and subnational elections conducted in the aforementioned region. The method used in research is case study, which is focused on three different cases (as examples illustrating main points of the study) and identifies the ways elections (partnering with other informal institutions) were used to stabilize the established order. In this paper author aims to investigate the factors contributive to the rigging nature of elections in limited access orders. It starts with the outline of the current state of the art in electoral studies. The overview of the research landscape demonstrates the existing multitude of approaches in the literature on elections, although the research field on electoral contestation in republics in the North Caucasus still remains a blank sheet. The results of the research favour findings of the previous scholars of elections in non-democratic countries. The significant correlation between the type of institutional environment and functions of elections takes place. In Kabardino-Balkaria, as in other socio-political entities characterized by limited access of individuals and organizations to rent, power, and privileges, despite the formal design of political system, the decision-making machinery mostly favours interests of groups within the ruling coalition. The central finding of the research is related to the functions of elections in limited access orders. According to the paper, elections contribute to the resilience and stable stay of ruling coalition in power throughout the whole postsoviet period. Elites in different administrative levels negotiate and conclude informal agreements to share the power, resources, and rents non-violently; in order to fulfill their commitments, they use election-rigging as the most incontrovertible way to accommodate interests of different elite and non-elite groups.
\end{abstract}

Key words: rigged elections; political institutions; Kabardin-Balkar Republic; North Caucasus; post-Soviet Russia; social movements; authoritarian resilience.

\section{ВЫБОРЫ КАК ПОЛИТИЧЕСКИЙ «ИНСТРУМЕНТ» В РУКАХ РЕГИОНАЛЬНЫХ ЭЛИТ: СЛУЧАЙ КАБАРДИНО-БАЛКАРСКОЙ РЕСПУБЛИКИ}

\author{
А.А. ТУМОВ
}




\author{
ФГБНУ «Федеральный научный иентр \\ «Кабардино-Балкарский научный центр Российской академии наук» \\ 360002, КБР, г. Нальчик, ул. Пушкина, 18 \\ E-mail: tumovasker@gmail.com
}

\begin{abstract}
Аннотация. Процесс государственного строительства в постсоветской России, который рассматривается политологами как пример «незавершенного перехода к демократии», позволяет нам исследовать роль «несправедливых выборов» и понять их скрытые и неочевидные функции в этом процессе. И если учесть, что выборы являются частью более широкой картины политического развития, изучение «закулисной» природы выборов необходимо для понимания контекста, результатов, а также мотивов деятельности основных участников электорального процесса.

Данная статья посвящена изучению федеральных и региональных выборов в КабардиноБалкарской Республике, северо-кавказском субъекте Российской Федерации. Использованный в работе метод «case studies», основанный на разборе трех кейсов, позволяет продемонстрировать как выборы в сочетании с другими неформальными институтами обеспечивают стабилизацию существующего порядка. Структура исследования выстроена в соответствии с порядком изучения роли несправедливых выборов в порядках ограниченного доступа. Обзор литературы, посвященной электоральным исследованиям, демонстрирует наличие большого количества подходов к изучению выборов, а также состояние слабой изученности этой проблемы в республиках Северного Кавказа. Результаты исследования подтверждают выводы ряда авторов об обусловленности природы избирательного процесса институциональным устройством политической единицы (в данном случае субъекта федерации). Кабардино-Балкария, несмотря на формальный дизайн политической системы, характеризуется ограниченным доступом индивидов и организаций к ренте, власти и привилегиям; процесс принятия решений выстроен в соответствии с необходимостью учета интересов групп, представляющих правящую коалицию.

Основной вывод статьи заключается в том, что институт выборов обеспечивает устойчивое пребывание правящей коалиции у власти в течение всего постсоветского периода. Элиты на федеральном и региональном уровнях используют выборы как инструмент формализации и воплощения в жизнь результатов скрытых договоренностей по разделу власти, рент и ресурсов между различными группами ненасильственным путем.
\end{abstract}

Ключевые слова: фальсифицированные выборы; политические институты; КабардиноБалкарская Республика; Северный Кавказ; постсоветская Россия; общественные движения; устойчивость режима.

\title{
Introduction
}

A variety of research has already been conducted with aim to establish causal links between elections and political orders; these schools represent attempts to analyse transition from authoritarian rule to democracy, transfer from conflict to postconflict society, institutional development of political orders, and electoral systems in federal states.

Transitology is a subfield of political science dealing with "transitions" of authoritarian regimes towards the establishment of democracies. Proponents of this academic tradition considered elections as one of the institutional prerequisites for democracy, emphasizing the notion of "free and fair elections," coined by Dahl and developed by his successors [Dahl 2000; Elklitt, Svensson 1997: 37]. The criticism triggered major shifts in this field - after obviously failed attempts to yield numerous 
concepts of "democracies with adjectives" researchers started to conceptualize the "institutionalized ambiguity" conversely - they adopted the suggestion of Linz to rely on subtypes of authoritarianism rather than to build subtypes of democracy and invented the term of "electoral authoritarianism" [Gasiorowski 2006: 110-111; Schedler 2006: 5]. The proponents of the concept share the stance that these regimes are semi-autocratic by their own choice and not because they lack capabilities to manage the full transition to democracy. Elections in this type of regime are free but hardly fair [Schedler 2002; Way 2006]. Electoral malpractices are manifestations of electoral engineering, according to Golosov, with his argument that authoritarian regimes are more likely to undertake comprehensive electoral reforms, aiming to make the system more consistent with the incumbents' goals [Golosov 2016: 381382].

Some researchers tried to transcend the dichotomy "democracy/authoritarianism" and concentrated onto the "grey zone," hybrid regimes, and the ways used by those regimes seeking to sustain their viability. The notion of "hybrid regime" implies the combination of both democratic procedures and authoritarian mechanisms within one political entity: the competitive democratic institutions, such as multiparty elections, rather mask the reality of autocratic domination because they are fraudulent and coerced; scholars agree that the type of hybrid regime falls somewhere between the conventional, closed authoritarian regime and a fully developed democracy or polyarchy [Diamond 2002; Cassani 2014]. Notwithstanding the recent developments in transitology (or, to be precise, "posttransitology"), authoritarian studies still provide a large room for discussion on the purposes and outcomes of holding elections. Elections, walking concertedly with informal practices (clientelism, tribal/kinship ties, etc.), contribute to the transformation of state institution and establishment of the neo-patrimonial system [Hinnenbusch 2010]. This perspective succeeds to account for authoritarian viability and legitimacy, because it takes elections into consideration as a part of the social order within a broader framework where patronage, ethnic ties, and other informal practices are intertwined with formal routines and are often treated as hindrances to democratization.

Some recent studies in liberal state- and peace-building, i.e. the transition from conflict to democracy rather than from authoritarianism to democracy demonstrate the links between violence and democratic institutions incorporated in conflict/postconflict societies [Collier 2009; Goodhand, Sedra 2013; Riese et al. 2010]. According to different cases regarding complex societies, the whole matter of electoral violence is partly attributable to the multiethnicity, resulting into violent ethnic conflicts. According to Snyder, implementation of democratic elections in conflict and postconflict societies might cause outbursts of violence and civilian conflicts [Snyder 2000]. The possible solution for preventing interethnic violence sometimes requires the implantation of informal rules aimed to ensuring the "fair" ethnic representation in government bodies [Miller 2006: 50-52]; the last point is crucial for analyzing and comprehending the politics in the Kabardin-Balkar Republic.

Numerous researches are made in line with institutional studies; they deal with emergence and formation of political institutions (i.a. elections, as they are highly 
formalized by very detailed and explicit rules but function intermittently). According to North, institutions are "rules of the game in a society", including both "formal" rules such as constitutions and laws enforced and protected by the state, and "informal" constraints such as "codes of conduct, norms of behavior, and conventions," which are generally enforced by members of the relevant group [North 1990]. The concept of violence is of crucial importance for comprehension of the contemporary institutional approach [North et al. 2009]. After the breakdown of the Soviet Union the establishment of electoral system started from scratch, and this process in regions was affected by elite struggles, ethnic cleavages, social movements' activities, and weaknesses of the federal center. These factors caused deviations in formation of electoral rules and legislation, which were supposed to be manifestations of newly emerged democracy, but in practice have led to different outcomes. Institutional studies pay prior attention to the combination of overt and covert rules, customs, and traditions, established in the political entity [Panov 2016; Боров 2016]. According to the concept of "rational choice institutionalism", political entrepreneurs and incumbents create rules to reduce the uncertainty and lower transaction costs[Панов 2004: 16]. In the course of time, those rules transform into proper institutions and become fundamental attributes of the current political system [Geddes 1995: 241]. In this vein, Gelman tries to explain the authoritarian nature of contemporary Russia and argues that researchers need to pay attention to the "path contingency" - a complex combination of structural (culture and legacies) and procedural (agents' actions restricted by existing structures) drivers of transformation [Гельман 2003; Гельман 2006: 57].

Given that we are dealing with the nexus between elections and stability/political order in a subnational polity over time it is justifiable to look over the literature on the role elections play in federations. Numerous studies were conducted in order to shed the light on Russian federal system. The significant point for discussing center-periphery relations is the common Russian phenomenon of "subnational authoritarianism" [Gibson 2005; The Politics 2010]. Scherbak explained the regional vote-rigging in Russia by the specifics of Russian fiscal policies [Щербак 2010] Panov and Ross have conducted a number of studies and have given insight into the functioning of regional legislative assemblies and the impact of federal reforms and changes in electoral legislatives on regional political arena [Panov, Ross 2013; Panov 2016]. In his comprehensive research on development of post-communist federalism in Russia Ross makes contributions into the nature of political parties and their absence in regional political processes in the 1990s [Ross 2002: 92-105]. Gelman endures this discussion, presenting the evolution of federal policies in the early 2000s and linking together the elites" "imposed consensus" and electoral reforms [Гельман 2005; Gelman 2002]. In a similar manner, Litvinova and Kokorhoeva have investigated the same processes up to the early 2010 s. They claim the causation of election-rigging in Russian regions to be the aftereffect of the federal policies, overlapping with endeavors of local elites [Кокорхоева 2012; Литвинова 2011].

As we can derive from the literature review, elections in different societies provide different results and impact future existence of political orders. Moreover, 
there are still unanswered questions concerning electoral characteristics and attributes in Russian regions, the functions elections provide and the way they are managed. Elections in the North Caucasus, notorious due to their massive fraud and voter turnouts, have been barely touched upon in a few studies in the context of Russian elections. Specific studies conducted in the North Caucasus slightly address ballots but fail to pay sufficient attention - they do not extend beyond a mere description of mechanical procedures and results.

The contemporary political relevance of the subject is crucial for understanding the Russian politics on both national and subaltern levels. If all reasonable men tend to believe the voting process having been manageable, the gaps and puzzles in the academic knowledge should cover the fundamental issues of elections, why they are held, and how they serve the needs of conductors (ruling coalition) and recipients (citizens). How ethnic-based power-sharing systems in multi-ethnic political entities contribute to the political stabilization? How incumbents use electoral mechanisms to distribute the power among their clients and prevent the encroachment of corrivals into the ruling coalition? To which extent federal elites may affect the regional electoral contestation and demand for the necessary results? Why, eventually, population is reluctant to challenge the authorities and accepts the rigged electoral outcomes?

The general research question refers to all aforementioned questions. As soon as I am trying to understand the social phenomenon and to identify its causes, reason, and key actors' motives for action, the question is of analytical character. Specifically, the current paper intends to answer the following question: how does election-rigging provide political stability in Russian subnational units?

For a more detailed analysis of institutions regulating the electoral system three cases were chosen in KBR. They were selected according to three dimensions mentioned above: first, the role of inter-ethnic power sharing in political stabilization; second, how local authorities deliver the results required by federal elites and regulate the power configuration; and third, to which extent incumbents are capable to impact the electoral outcomes in order to excommunicate the oppositional parties from access to power. In order to maintain the consistence of case studies, all three selected cases deal with legislative elections in KBR during the post-Soviet period.

From the general research question presented earlier we might derive the good reason to assume that the ruling coalition in Kabardino-Balkaria prefers to consider elections as a tool of political stabilization. The notion of political stability refers to the state of the political object when it has the capacity to prevent its non-survival [Dowding 1983: 238-239]. One can say that the political object either does or does not possess the capacity to withstand contingencies. Therefore, there are no degrees of stability - the system is either stable or unstable. In order to develop our assumptions, we need to identify the possible factors contributing to the political object's instability. Martin Svolik in his research emphasizes that authorities may be toppled down due to their inability to either solve the puzzle of authoritarian control (e.g. popular uprising as a result) or manage the problem of power-sharing (e.g. coup d'état as a result) [Svolik 2012: 5-13]. The following assumptions will be constructed on the basis of this consideration. 
The first assumption deals with the ruling coalition's desire to control the population and prevent possible unrests and popular uprising. I assume that the ruling coalition in limited access orders with ethnic-based societal cleavages uses rigged elections for the purposes of political stabilization by means of ethnic power-sharing.

The second assumption relates to the intra-elite relations. Kabardin-Balkaria is not an independent state, and local elites have to focus on addressing the needs of superior groups on the national level. Adjusting Svolik's idea to the particular case of $\mathrm{KBR}$, we allege that subnational incumbents need to solve the problem of powersharing taking into consideration demands from both federal and regional parties. Hence, we arrive at the following hypothesis: in subnational polities with limited access orders election-rigging ensures the outcomes of informal plea bargain between subnational and national political elites.

\section{The making of modern political and electoral regime in KBR}

The historical narrative of Kabardin-Balkar political development since the Soviet Union's breakdown is essential for understanding the way the contemporary electoral system and its functions emerged and have changed over the past decades. In this chapter I intend to present the main milestones of subnational political process, shortly describe the evolution of democratic institutions (i.a. elections), and delineate impact of the federal-level policies on the local vicissitudes and conflictual complexities.

The starting point for historical narrative on elections in post-communist Kabardino-Balkaria is 1989, when the political movement of Perestroika led to democratization of the Soviet political system. The notorious electoral system, which had been existing since the late 1920s, with its one-party ballot and voter turnout in the vicinity of 100\% [White 1985: 217], was reformed by Gorbachev's amendments. The 1989 Soviet legislative election was the first opportunity citizens ever had of casting their ballots for any but the official Communist Party candidates. The freshly elected Congress of People's Deputies represented (more or less) the whole universe of political spectrum and pursued the ensuing democratization, concurrently undermining the Communist Party's (CPSU) influence.

The rapid democratization affected regions, including Kabardino-Balkaria. Firstly, Perestroika being started, different newly-established independent ethnicoriented non-governmental organizations claimed their adherence to the principles of ethno-cultural development and democratization and denied to recognize the primacy of CPSU. Secondly, the 1990 republican Supreme Soviet election signified the emergence of the competitive political arena. Although the sham ballots took place in three of eight precincts, the political opposition managed to advance and enter the legislature [Такова 2010: 92].

The regional nomenklatura with republican party secretary Valeriy Kokov as a leader was challenged by the two newly emerged nationalistic factions - Kabardian and Balkarian. Having caught the wind of the fading CPSU's influence, Kokov swapped his position to the chairman of the Supreme Soviet, particularly given that the Gorbachev's reforms heaved the Soviets (legislatures) to the zenith of power. 
Moreover, after the suspicious castling Kokov made a grave political mistake, being espied cooperating with the failed 1991 Moscow coup leaders who sought to roll back the liberal reforms. The pro-democratic forces organized a public rally and raised the population to resist nomenklatura; Kokov and other high-rank officials were compelled to step down [Шорова 2010: 120-121]. Nonetheless, his political calculus and ability to build networks boosted him during the 1991 Kabardin-Balkar presidential election - he was elected as the first President of KBR [Боров 2016: 158]. During 1991-1997 he tried to strengthen his position: firstly, he earned the trust of federal authorities due to his ability to deliver necessary electoral and referendum results and to prevent "the Chechen scenario" (the neighboring Republic of Chechnya claimed its independence and attempted to withdraw Russian Federation; those events culminated into the civil war; according to a common attitude, all Caucasian republics were on a brink of armed conflict). Secondly, he was successful in confronting the inner opposition: the most compliant and flexible entrepreneurs were co-opted into the power structures, the most radical ones were detained on the political outskirts. The opposition had been eliminated by 1997; the same year, the first post-Soviet republican Constitution was adopted, the Parliamentary election strengthened Kokov's party, and he himself won the uncontested presidential election being a single candidate [Ross 2002: 161; Казенин 2009: 77]. As a result, the successful authoritarian consolidation (procedures become routinized and internalized is social, institutional, and psychological life) in KBR was achieved in 1997.

The decline of federal power and the country's fragmentation in the 1990s were succeeded by Moscow's attempt to establish control over the most important administrative levers and create robust vertically structured political system [Литвинова 2011: 156-157]. The Putin's federal government conducted two arrays of political reforms and changed the legislation resulting in the significant metamorphoses of the domestic political system [Шхагапсоев и др. 2011: 182-183]. The large-scale campaign to bring regional statutes and republican constitutions in accordance with the Constitution of the Russian Federation led to the unification of legislations; the governors' elections were replaced by President's appointments; in accordance with the electoral reform, single-mandate constituencies were abolished and succeeded by the proportional representation model; the country was divided in seven federal districts, with chairmen ("polpreds") thereof controlling regional executives and securities. Reforms have resulted in reasserting federal authority over the regions; the political system has been permeated by "power vertical" designed to maintain cohesion of the ruling elite.

Reforms significantly impacted the Kabardin-Balkar power model. The republican Constitution lost its trappings of statehood such as notions of "republican sovereignty" and "republican citizenship". The bicameral Parliament became unicameral; some of its Committees lost their validity. The most visible change was that the President has no longer been an elected official - according to the new legislation, his empowerment has been carried out on the proposal of President of Russia by the regional Parliament for five years ${ }^{1}$.

\footnotetext{
1 Закон Кабардино-Балкарской Республики от 12 июля 2005 года № 52-Р3 «О поправках к Конституции Кабардино-Балкарской Республики» // «Кодекс» - электронный фонд правовой и
} 
The regional authorities faced a number of challenges during the reform period. First of them was a fierce struggle in the 1999 and 2002 elections. The 1999 Russian State Duma election in the Kabardin-Balkar precinct was tested by the serious clash between incumbent candidate Sohov and independent self-nominee Teuvazhukov'; the public opinion associated the latter with clandestine activities of Arsen Kanokov, the well-known Kabardian tycoon who had been opposing the republican authorities over a long period of time. During his campaign Teuvazhukov spent a considerable amount of money but did not succeed (Sohov was elected as a State Duma deputy), even though his campaign was marked as well-conducted and very convincing [Боров 2017: 166]. The 2002 presidential election in KBR was expected to be an ordinary Kokov's triumph; nevertheless, "big money politics" initiated by Kanokov hindered the incumbent's victory by landslide - Kokov encountered a ferocious resistance by Kanokov's proteges. Kokov had not been reluctant to win at all costs; his scandalous electoral campaign stirred scandalous fallout in Russian media because of breaching the electoral legislation - harassment of oppositional candidates, over-expenditure of electoral budget, buying of votes, and coercing students to go to the ballots [Тумов 2017: 122]. However, Kokov managed to strengthen his positions by meeting the requirements of the federal authorities - KBR voted for Putin in 2000 and the newly emerged party of power "United Russia" in 2003 with a sizeable discipline; these results had a confidence-building effect among national elites towards Kokov².

In September 2005, after Kokov had resigned the post for health reasons, in accordance with the new legislation, Putin appointed aforementioned Arsen Kanokov as the Head of KBR (the new title of the post). The first month of his leadership was marred by the raid of Wahhabi militants on Nalchik, when more than 140 people were reported to have been killed during the ensuing shooting. The subsequent surge of violence exercised by both Jihadist insurgents and security agencies had been shaking the North Caucasus for decade. The state of emergency in republics had become a routine affair impeding its economic growth and influx of tourists; moreover, the precarious situation was used by authorities to justify the further political restrictions ${ }^{3}$. In the meantime, republic was quaking under the rise of new nationalist movements. Being backed by support of powerful State Duma deputy Zalikhanov, the newly established Balkarian social movement contested the authorities over the land disputes and demanded to lift the moratorium on the land privatization and to distribute it among local communities. The situation was

нормативно-технической документации. URL: http://docs.cntd.ru/document/802041439 (дата обращения: 05.08.2018).

${ }^{1}$ Expert 3, Lawyer, interview conducted in Nalchik 17.09.2017.

2 Маркедонов С. Кабардино-Балкария: Конец эры Кокова. 22 сентября 2005 г. // Сайт Международного правозащитного общества «Мемориал». URL: http://old.memo.ru/hr/hotpoints/caucas1/msg/2005/09/m48064.htm (дата обращения: 05.08.2018).

3 Казенин К., Стародубровская И. Северный Кавказ: Quo Vadis? // «Полит.ру» информационно-аналитический портал. URL: https://polit.ru/article/2014/01/14/caucasus/ (дата обращения: 05.08.2018). 
exacerbated by Kanokov's political stance and allegations, which Balkar entrepreneurs perceived to be "pro-Circassian" and "nationalistic." In addition, the nascent Kabardian (Circassian) social movement raised its head, demanding to compensate the historical grievances and opposing Balkarian pretensions. The political tension between Kanokov and those close to former president Kokov had also affected the political affairs [Казенин 2009: 84-90].

The electoral process in the meantime did not undergo major changes, except for incredibly rising outcome indicators of federal elections in KBR. During 20072012, electoral results had been equilibrating to median 90 per cent of voter turnout and support of incumbent candidates - "United Russia" in the State Duma elections (2007, 2011) and Dmitriy Medvedev and Vladimir Putin in presidential elections $(2008,2012)$. On the other hand, regional electoral results left room for political contestation, as far as large Duma parties (Communist Party, Liberal Democratic Party, and "A Just Russia") were represented in the Parliament of KBR. Furthermore, in 2012 federal legislation reinstated presidential elections in regions, allowing regional legislatures to maintain the desired model; nevertheless, Kabardino-Balkaria used the opportunity to recruit the Head of the republic without elections [Panov 2016: 360].

The political and economic underperformance fostered Kanokov's dismissal in 2013. He was succeeded by Yury Kokov, the former chairperson of National Antiterror Committee; his designation has probably been connected with the preparation to the oncoming 2014 Winter Olympics - Kokov was expected to put an end to the continuing religious insurgence due to his experience of working in securities ${ }^{1}$. This mission has partially been accomplished; however, experts consider it as a result of the Federal Security Service's efforts, rather than of governors'. Another major reason for that was the exodus of Salafists to the Middle East, where they sought to join expanding Islamic State ${ }^{2}$. Furthermore, most of the problems raised by social movements have been unanswered; in contrast with Kanokov, Kokov, Kabardian himself, has been accused of sympathizing with Balkars and promoting pro-Balkar policies; some activists were insulted by the upcoming 2014 Olympics in Sochi, a cite of one of the largest massacres of Circassians in the XIX century (Kabardians are one of the Circassian sub-ethnic groups) ${ }^{3}$.

During Kokov's presidency the electoral process in KBR has conserved its previously gained attributes, i.e. high indicators of both voter turnout and wide support for incumbent candidates. Thus, in the 2018 presidential election Vladimir Putin obtained $93,38 \%$ votes in KBR, which became the highest result among

\footnotetext{
${ }^{1}$ Expert 5, Social Activist, interview conducted in Nalchik, 24.08.2017.

2 ФСБ: бандподолье на Северном Кавказе практически полностью ликвидировано // ТАСС. 19 декабря 2017 г. URL: http://tass.ru/proisshestviya/4825781 (дата обращения: 05.08.2018).

3 Zhemukhov, Sufian. The Circassian Dimension of the 2014 Sochi Olympics. Sept. 2009 // Circassian World - Independent web source. https://web.archive.org/web/20091011120907/http://www.circassianworld.com/new/general/1382circassian-dimension-2014sochi-szhemukh.html (last accessed: 05.08.2018).
} 
Russian regions. Nevertheless, independent electoral monitoring groups and observers were reporting about voting irregularities and ballot stuffing ${ }^{1}$.

Thus, a historical account of post-Soviet political development of KabardinBalkar Republic shows the rise and conservation of electoral irregularities, e.g. enormously high voter turnout, support for incumbent candidates, and permanent reports from polling organizations about ballot staffing. The next sections are focusing on different dimensions and characteristics of elections in KBR: inter-ethnic power sharing, bargain between federal and regional elites, and manifestation of local intra-elite struggle in electoral fraud.

\section{Electoral mechanisms of inter-ethnic power sharing}

The handful literature on informal political institutions in the North Caucasus is replete with the notion of ethnic quota that consists in allocation of public offices among representatives of key ethnic groups; this distribution aims to provide their equal access to power [Стародубровская, Казенин 2016]. Undoubtedly, the implementation of this principle transpires behind the scenes, given that it nominally contradicts to the basic provisions of Russian Constitution [Литвинова 2011: 240]. Some experts consider this informal institution to be effectively resolving intra-elite conflicts [Адиев и др. 2017], while the others point out the loss of public interest towards the equal distribution of power [Казенин 2010: 208-209].

Although the origins of ethnic quota principle of power-sharing were built on during the Soviet period, the late 1980s democratization eroded this informal convention. It was brought back to life after the March, 1990 elections to the Russian and the Kabardin-Balkar Supreme Soviets; according to the results, none of Balkar deputies was elected to the Russian Soviet, and only 18 - to the republican Soviet (consisting of 160 members). The immediate public outcry compelled authorities to conduct re-elections in several precincts in order to increase the former number to 1 and the latter - to 21 [Шорова 2010: 101]. Nevertheless, Balkar political leaders stated the "inequality" in distributing the power positions; parliamentary sessions became vivid evidence of the ethnic-based elite cleavage. In the meantime, Kabardian non-governmental organizations denounced corruption and political elite's reluctance to guarantee democratization. Both social movements stood up against each other and the ruling group - former Soviet nomenklatura. The new form of political manifestation - "conventions of people" - took place in 1991-1992; those conventions demanded to divide the republic along ethnic lines. Several demonstrations run by opposition barely escaped the non-violent arena; during the 1992 political crisis federal troops were deployed in Nalchik to maintain law and order [Шорова 2010: 144-146].

\footnotetext{
${ }^{1}$ Юрасова, Татьяна. Все подходы записаны. 3 июня 2018 г. // Электронное периодическое издание «Новая газета». URL: https://www.novayagazeta.ru/articles/2018/06/03/76701-vsepodhody-zapisany (дата обращения: 05.08.2018); Явка в Кабардино-Балкарии превысила результаты прошлых выборов. 19 марта 2018 г. // Интернет-СМИ «Кавказский узел». URL: https://www.kavkaz-uzel.eu/articles/318010/ (дата обращения: 05.08.2018).
} 
Politicians on the middle ground headed by newly elected President Valeriy Kokov tried to divide the opposition and co-opt moderate leaders into the ruling coalition. He managed to establish the power-sharing system among the highest officials: Kabardian president, Balkar prime-minister, and Russian speaker of Parliament. In 1993, following the lead of President Yeltsin of Russia who eliminated the Russian Supreme Soviet and replaced it with the State Duma, Kokov dissolved the republican legislature and held the election to the newly established Parliament of KBR. None of the opposition deputies from the Supreme Soviet advanced to the new convocation, as it was consisting of representatives of large businesses and former communist nomenklatura. Furthermore, the number of Balkar deputies in the new convocation increased and exceeded the share of the population. This number has been stable thus far; the ethnic composition of parliamentary convocations is illustrated in the table below (Table 1).

\section{Ethnic Composition of Parliamentary Convocations}

Table 1

\begin{tabular}{|c|c|c|c|c|c|c|c|c|c|c|}
\hline Ethnic group & \multicolumn{2}{|c|}{$1^{\text {st }}$ conv. } & \multicolumn{2}{|c|}{$2^{\text {nd }}$ conv. } & \multicolumn{2}{|c|}{$3^{\text {rd }}$ conv. } & \multicolumn{2}{|c|}{$4^{\text {th }}$ conv. } & \multicolumn{2}{|c|}{$5^{\text {th }}$ conv. } \\
\hline Kabardians & 42 & $58,33 \%$ & 39 & $54,17 \%$ & 61 & $58,10 \%$ & 45 & $62,50 \%$ & 34 & $49,28 \%$ \\
\hline Balkars & 11 & $15,28 \%$ & 14 & $19,44 \%$ & 19 & $18,10 \%$ & 13 & $18,06 \%$ & 12 & $17,39 \%$ \\
\hline Russians & 18 & $25,00 \%$ & 15 & $20,83 \%$ & 20 & $19,05 \%$ & 12 & $16,67 \%$ & 18 & $26,09 \%$ \\
\hline Other & 1 & $1,39 \%$ & 4 & $5,56 \%$ & 5 & $4,76 \%$ & 2 & $2,78 \%$ & 5 & $7,25 \%$ \\
\hline Total number & \multicolumn{2}{|c|}{72} & \multicolumn{2}{|c|}{72} & \multicolumn{2}{|c|}{105} & \multicolumn{2}{|c|}{72} & \multicolumn{2}{|c|}{69} \\
\hline Source: Arch & & arliam & & & & & & & & \\
\hline
\end{tabular}

The data provided in the Table 1 displays the results of ethnic power-sharing mechanisms. The number of Balkars exceeds their share in population (18\% in the Parliament against $12 \%$ in general); the reasonable assumption would be the higher voting activity of Balkars during the ballots, but the official figures confute this thesis - voting in Balkar-populated districts does not significantly deviate from the general pattern ${ }^{1}$. Apparently, the formation of authorities is regulated by informal agreements within the ruling coalition. This statement had been explicitly confirmed by the Kabardin-Balkar Declaration of Sovereignty adopted in 1992; it included an item aiming to ensure the equal representation of main "titular nations" in authorities [Боров и др. 1999: 117-118]. Although the Declaration lost its judicial validity during the recentralization period, this informal rule still has been regulating the political arena. Hence, three top high official positions (president, prime-minister, speaker of Parliament) have always been held between Kabardian, Russian, and Balkar correspondingly (with the exception of the current government with Balkar prime-minister and Russian parliamentary speaker). Additionally, president ensures a pro rata ethnic balance while assigning ministerial portfolios. Moreover, the distribution of chairmanships in parliamentary committees is regulated likewise, in

\footnotetext{
${ }^{1}$ Website of the Central Electoral Commission of the Russian Federation, http://www.cikrf.ru/; Website of the Kabardin-Balkar Electoral Commission, http://www.kabardin-balkar.izbirkom.ru/
} 
accordance with the permanent share of ethnic representation. The only exception is the Committee on inter-ethnic relations that has three chairpersons (Kabardian, Balkar, and Russian). For other committees, if the premature termination of mandate takes place, the new chairman is selected among deputies representing the predecessor's ethnicity ${ }^{1}$.

The similar trend transpires while looking at the State Duma electoral results (Table 2). Among three deputies from Kabardino-Balkaria in the fifth Duma convocation (2007) Russian, Kabardian, and Balkar were represented. Arsen Kanokov was elected as a Kabardian deputy but could not perform his functions because of his presidency; he therefore passed his mandate to Kabardian Adalbi Shhagoshev and preserved the quota. The 2011 Duma election was conducted by proportional representation; due to high voter turnout, the number of deputies from KBR increased to 4, with 2 Kabardians, 1 Balkar, and Russian. The 2016 election was carried out by mix of proportional representation and single-member constituencies systems, but the number of deputies and ethnic quota remained unchanged. It should be mentioned that two deputies of the upper house of Russian legislative assembly, the Federation Council, were elected in 1993 and met the requirements of ethnic quota (Kabardian Kokov and Balkar Cherkesov). Since 1996 members of the Council have been appointed by the regional authorities; nonetheless, the deputation from KBR always consist of one Kabardian and one Balkar.

\section{Ethnic Representation of the State Duma deputations}

Table 2

\begin{tabular}{|l|c|c|c|}
\hline Ethnicity & $5^{\text {th }}$ conv. $(2007)$ & $6^{\text {th }}$ conv. (2011) & $7^{\text {th }}$ conv. (2016) \\
\hline Kabardians & 1 & 2 & 2 \\
\hline Balkars & 1 & 1 & 1 \\
\hline Russians & 1 & 1 & 1 \\
\hline \multicolumn{2}{|l}{ Source: Wikipedia. The Free Encyclopedia } \\
\hline
\end{tabular}

Analyzing phenomenon of ethnic quota in government and parliamentary agencies of KBR, one should admit that this rule roots in informal intra-elite agreements and was cultivated in order to prevent the growing activities of social movements and to divide the opposition. Categorizing key actors in this process, we can emphasize the power struggle between three parties - the former Soviet nomenklatura led by Kokov, the Kabardian social movement, and the Balkar social movement. The two latter were backed by their constituencies enabling them to organize strikes, demonstrations, and rallies - in the early 1990s ethnicity became a bridge between politicians, intelligentsia, criminal groups, and general public [Силаев 2015: 27]. Kokov managed to drive a wedge between leaders of oppositional parties by co-opting the moderate ones into the ruling coalition by means of appointments and rigged elections; this allowed him to protect his and his clients'

\footnotetext{
${ }^{1}$ Archive of the Parliament of the Kabardin-Balkar Republic.
} 
access to power and positions ${ }^{1}$. Having gained access to the power and rent, the newly co-opted oppositional entrepreneurs changed their political stance and contributed to the resilience of authoritarian regime: they distanced themselves from oppositional groups and brought their cliques with them. Nowadays, even though the previous social movements have vanished in all but names and been replaced by other political groups, the informal rule of quotation has still been implemented and serves the purposes of justifying rigged elections by providing equal access to power for all ethnic groups.

\section{Elections under bargain}

This case deals with the competition between parties during federal legislative elections. Political parties have been important not only for representing political constituencies, but also for recruiting candidates and integrating groups and individuals into administration. It should be pointed out that the during the 1990s the influence of parties in Russian regions was insignificant, because Kremlin had no interest in developing party of power, preferring to look for a foothold on different platforms (Party of Russian Unity and Accord, Our Home - Russia etc.); likewise, governors were attempting to strengthen their positions via local "political machines," which had nothing in common with traditional political parties, or through recruitment of their cliques. Thus, in Kabardino-Balkaria up to 80 per cent of the members of the Parliament represented economic elite, factory directors, or businessmen; similarly, the number of state officials among deputies was very high [Ross 2002: 130-131]; nonetheless, only 14\% of deputies represented different political parties [Литвинова 2011: 151].

The situation shifted in early 2000s, when federal authorities took several steps to unify the political landscape and to build the "power vertical." One of those steps represented an attempt to steel the established party system and strengthen the prior party "United Russia" [Панов 2006]. Scholars tend to agree that authoritarian parties affect regime in a positive way. They endow it with the possibility to prevent factionalism among elites; moreover, political parties in non-democracies are means through which regimes may distribute rents and support; frequently this embodies in the form of co-optation or patronage [Svolik 2012: 163]. According to Blaydes, authoritarian regimes tend to use parliamentary elections as a tool to manage domestic political elite, in order to have staunch allies contributing into regime stability, in exchange providing them with numerous opportunities for moneymaking, influence, and access to state resources [Blaydes 2011: 48-49]. Due to recentralization reforms Russian elites managed to overcome the division in factions and to appear as the consolidated and highly integrated political group. This "imposed consensus" promoted severe restrictions of electoral competition and hampered penetration into elections and campaigning possibilities for oppositional parties [Гельман 2005: 23]. Experts claim that all regional legislatures are designed in order to guarantee a majority of seats for newly-created "United Russia" and a

${ }^{1}$ Expert 4, Human Rights Activist, interview conducted in Nalchik, 07.08.2017. 
minority - for the so-called "second-order parties" [Panov, Ross 2013: 373]. Panov and Ross distinguished competitive and hegemonic authoritarian regimes in Russian regions with good electoral performance of United Russia but different contested arena: competitive regional regimes still undergo genuine competition among parties, whilst hegemonic ones eliminate electoral competition completely and show overwhelming support for party of power [Panov, Ross 2013: 371].

Sub-national polities in federation has been exercising their own unique party systems. Even highly centralized Russian Federation with its imposed power vertical has a number of diverse electoral systems that make a significant distinction between units of the country. Regions can exercise either single-member district system or proportional representation type of parliamentary elections, or combine two previous options; Kabardino-Balkaria have adopted full proportional representation system with party list voting. According to Panov and Ross, the type of electoral system impacts the degree of electoral competition - regions with party list voting tend to be less competitive [Panov, Ross 2013: 384]. This can be explained by the fact that in single-member district voting oppositional candidates are able to enter elections as self-nominees, whilst party list voting purposes to retain undesirable candidates from participation.

However, if we have a look at legislative electoral outcomes in KabardinoBalkaria since after 2007 (Table 3), we will notice numerous anomalies related to results of some "second-order parties". The figures are inexplicable in terms of voters' deliberate choice. For instance, within two years Communist Party, Liberal Democratic Party, and "A Just Russia" had improved their performance from mediocre results in 2007 to the relative success in 2009. Thereafter, LDPR and JR had underperformed in 2011 and 2016 State Duma elections, although managed to obtain more votes in interim 2014 parliamentary election. Apparently, the rapid change of political stances among voters is an insufficient explanation.

Table 3

\section{7-2016 Legislative Elections Results}

\begin{tabular}{|l|c|c|c|c|c|}
\hline Parties & $\begin{array}{c}2007 \\
\text { SD election }\end{array}$ & $\begin{array}{c}2009 \\
\text { parliamentary } \\
\text { election }\end{array}$ & $\begin{array}{c}2011 \\
\text { SD election }\end{array}$ & $\begin{array}{c}2014 \\
\text { parliamentary } \\
\text { election }\end{array}$ & $\begin{array}{c}2016 \\
\text { SD election }\end{array}$ \\
\hline $\begin{array}{l}\text { "United Russia” } \\
\text { (UR) }\end{array}$ & $96.12 \%$ & $72.29 \%$ & $81.91 \%$ & $65.28 \%$ & $77.71 \%$ \\
\hline $\begin{array}{l}\text { Communist } \\
\text { Party (CPRF) }\end{array}$ & $1.72 \%$ & $8.36 \%$ & $17.63 \%$ & $11.55 \%$ & $18.90 \%$ \\
\hline $\begin{array}{l}\text { Liberal } \\
\text { Democratic } \\
\text { Party (LDPR) }\end{array}$ & $0.41 \%$ & $7.02 \%$ & $0.08 \%$ & $5.10 \%$ & $0.15 \%$ \\
\hline $\begin{array}{l}\text { A Just Russia } \\
\text { (JR) }\end{array}$ & $1.41 \%$ & $12.26 \%$ & $0.23 \%$ & $11.51 \%$ & $2.09 \%$ \\
\hline Source: websic & Cent & & & \\
\hline
\end{tabular}

Source: website of Central Election Committee of Russian Federation 
The case could be explained with comprehension of strategy of republican authorities - the genuine conductor of the process. Given that authorities can control the desirable results, they may use this resource in order to ensure strong positions for "party of power" "United Russia" in national elections, meanwhile making advances for other influential federal actors (e.g. "second-order" parties) in regional parliament. The possible explanation could be related to the budget policies of Russian authorities. Indeed, studies have demonstrated positive correlation between electoral results for incumbents and budget subsidies in Russian regions throughout the entire post-Soviet period [Щербак 2010]. Stated differently, the better incumbent candidates performed in regional precincts during national elections, the more subventions region obtained from the federal governmental budget. The incentive to suggest the shift in the fiscal stance of Russian authorities during the last decade has been absent.

Table 4: 2007-2016 State Duma Elections Results

\begin{tabular}{|l|c|c|}
\hline & Voter turnout in RF & Voter turnout in KBR \\
\hline 2007 SD election & $67.71 \%$ & $96.68 \%$ \\
\hline 2011 SD election & $60.10 \%$ & $98.33 \%$ \\
\hline 2016 SD election & $45.51 \%$ & $90.11 \%$ \\
\hline Source: website of Central Election Committee of Russian Federation \\
\hline
\end{tabular}

The next assumption relating to electoral outcomes in KBR is linked with the enormously high voter turnout. In the State Duma elections (Table 4) the KabardinBalkar Republic has been demonstrating intense activity of citizens that significantly exceeds national figures. The possible explanation of this anomaly is the federal legislation, in accordance to which federal units with the higher voter turnout have more representatives in the State Duma ${ }^{1}$. Thus, KBR as a region with appropriate figures is represented by 4 deputies in federal legislature. This allegation was confirmed by interviewed expert in legal support of electoral campaigns and deputy of the Parliament of KBR. They explained the strategy of republican authorities by determination to have enough policy-providers, lobbyists, and supporters on the federal level, within the federal authorities ${ }^{2}$.

\section{Local intra-elite struggle and electoral fraud}

The current analysis is intended to shed the light on the circumstances of 2009 legislative election in Kabardino-Balkaria. As it has already been mentioned above,

\footnotetext{
${ }^{1}$ Федеральный закон от 18 мая 2005 г. № 51-Ф3 «О выборах депутатов Государственной Думы Федерального Собрания Российской Федерации» (с изменениями и дополнениями) // ГАРАНТ.РУ - информационно-правовой портал. URL: https://base.garant.ru/12140155/ (дата обращения: 05.08.2018).

${ }^{2}$ Expert 2, Deputy of the Parliament, interview conducted in Nalchik 11.09.2017; Expert 3, Lawyer, interview conducted in Nalchik 17.09.2017.
} 
in 2005 after the first president Valeriy Kokov's resignation Russian leader Vladimir Putin was supposed to nominate his candidate as new president of KBR. During the pre-appointment interregnum Khachim Karmokov had been being considered to be Kokov's successor ${ }^{1}$. Karmokov has been a prominent statesman in KBR since the late 1980s: he had been presiding the republican Supreme Soviet until 1993, had been deputy of State Duma before he took over Chairman's office of Russian Accounts Chamber; in 2001 he became a member of the Federation Council, the upper house of the Russian national legislature ${ }^{2}$. Nevertheless, Arsen Kanokov was appointed new president of Kabardino-Balkaria. Karmokov's influence and political significance empowered him to stay as a political heavyweight in Kabardino-Balkaria. In 2007, after "A Just Russia" party had been founded, Karmokov became the chairman of party's regional branch, still being a member of the Federation Council.

The political confrontation between Kanokov and Karmokov had become apparent in 2007. In the State Duma election "A Just Russia" garnered only $1.41 \%$ of votes (against "United Russia" with 96.12\%); immediately upon the election Karmokov accused the republican authorities of ballot-rigging ${ }^{3}$. At the extraordinary session of Parliament deputies urged Sergey Mironov, leader of "A Just Russia," to withdraw Karmokov from the Federation Council; Mironov had refused - his reluctance probably stemmed from urge to protect his partisan and to prevent his replacement by the member of "United Russia"4 . Concomitantly, regional media launched a public campaign against Karmokov and his party, accusing him of cooperation with the so-called "Balkar nationalists" [Кынев 2009: 102]. In 2009, on the eve of the republican parliamentary election, Mironov had abruptly excluded Karmokov from the Federation Council; he was replaced by Albert Kazharov, Kanokov's former chief of staff and member of "United Russia". Preparing to the looming election, Karmokov compiled a party list with his own name at the top, but was discharged from his chair by Mironov at the last moment; Karmokov's office was taken by his deputy Svetlana Azikova [Кынев 2009: 102]. She compiled a new

1 Губин? Каноков? Кармоков? 22 сентября 2005 г. // Газета Юга: сайт URL: http://www.gazetayuga.ru/archive/2005/38.htm (дата обращения: 05.08.2018).

2 Кто возглавлял Счетную палату РФ. Досье. 22 мая 2018 г. // ТАСС, информационное агентство: сайт. URL: http://tass.ru/info/5221704 (дата обращения: 05.08.2018).

3 Сенатор от Кабардино-Балкарии отозван из Совета Федерации. 20 декабря 2007 г. // Интернет-СМИ «Кавказский узел». URL: https://www.kavkaz-uzel.eu/articles/129282/ (дата обращения: 05.08.2018); Парламент Кабардино-Балкарии просит досрочно прекратить полномочия своего представителя в Совфеде. 20 декабря 2007 г. // ИА Regnum, информационное агентство: сайт. URL: https://regnum.ru/news/935149.html (дата обращения: 05.08.2018).

${ }^{4}$ Сенатор отзывают по партийной линии. 21 декабря 2007 г. // Газета «Коммерсант»: сайт. URL: https://www.kommersant.ru/doc/838532 (дата обращения: 05.08.2018); Депутаты Парламента Кабардино-Балкарии решили сменить сенатора. 20 декабря 2007 г. // Lenta.ru новости России и мира сегодня: сайт. URL: https://lenta.ru/news/2007/12/20/karmokov/ (дата обращения: 05.08.2018).

${ }^{5}$ Кажаров Альберт Хатуевич. 25 апреля 2014 г. // Интернет-СМИ «Кавказский узел». URL: https://www.kavkaz-uzel.eu/articles/228558/ (дата обращения: 05.08.2018). 
party list; as a result, the party's performance in parliamentary election was more successful comparing with the previous $(7.02 \% \text { against } 1.41 \%)^{1}$.

While appraising the situation, two questions may be derived for analysis. The first question relates to party leader Mironov's incentive to replace amicable Karmokov by the representative of rival party, although he hesitated to do that after the first appeal. The second one is linked with overnight increased popularity of "A Just Russia." The possible answer might be connected with informal agreement between Mironov and president Kanokov. The outcome looks like exchange of resources between two political patrons. Kanokov takes down his adversary, in return providing party with seats in Parliament. In his turn, Mironov strengthens his party's position in Parliament (in order to increase his political clout); instead he has to replace his client [Тумов 2017: 127]. The relevant notion of "subversive institutions" has been created to define the use of formal law for purposes of de-facto institutional structures [Гельман 2010; Olsson 2016: 40] in this case legitimate procedures of elections and deputy mandate allocation authorized parties to achieve their goals without violating the official rules.

\section{Conclusion}

The case studies provide insights into the forces at work on regional level in Kabardin-Balkaria. To put the results into the academic discussion, it is necessary to define the types of key actors with their resources and institutional patterns - or, at least, classification, as far as a number of individuals and organizations participating in the described processes within this research does not appear to be encompassed.

It is reasonable to start off with the "ruling coalition" in Kabardino-Balkaria. Using this term, I implicate that subnational political elites are not a single actor and can be divided along ethnic lines, in patronage networks, bloodline clans etc. In accordance with the case studies, different individuals act in this role and compete with each other, but this does not contradict to the main idea of ruling coalition's aspiration - to retain access to rents and state resources, which are drivers to fight for power and are needed to stay in power. This aspiration pushes them to form alliances with another groups in order to protect themselves from tempestuous risks; interestingly, some members of ruling coalition may fall victims during the power struggle (Karmokov's descent as an example). Republican elites derive their legitimacy from two sources. First of them is the so-called "mandate" from supreme elites - e.g. presidential appointment of the Head of the Republic, or informal links with federal political heavyweights and kingpins. The second source is the local population, which may choose to support or challenge the authorities. Coincidently, those two forces may also appear the reason of their downfall. Therefore, in order to sustain their stable stay in power, elite groups need to involve in complex network of behind-the-scenes agreements and to use rigged elections as a means to fulfill their

\footnotetext{
${ }^{1}$ Website of the Central Electoral Commission of the Russian Federation, http://www.cikrf.ru/; Expert 1, Deputy of the Parliament, interview conducted in Nalchik, 07.08.2017.
} 
commitments - their resources such as access to power and informal mechanisms allow to fabricate electoral outcomes in favour of particular candidates and parties.

The menace for the ruling coalition "from below" is the population; social movements represent its active part in the community with ethnic-based cleavages. Although both Kabardian and Balkar social movements are considered to be independent, they partially consisted of representatives of governmental bodies, local self-government agencies, and small and medium businesses, which gave rise to the increase of movements' pressure. Those nationalist organizations had undoubtedly possessed violent potential, given the circumstances of the 1990-1993 protests. This access to violence made ethnic leaders and entrepreneurs able to conduct a dialogue from a position of strength and induced Kokov's group to start the negotiating process. However, ethnic organizations could not use their coercive potentials at their full capacity because of the involvement of federal military agencies. After the cooptation and obtaining access to the power and rent oppositional leaders contributed to the resilience of authoritarian regime by promoting splits within movements and including their parts into new patronage networks.

Although the federal elite is rather set of semi-independent individuals and organizations than a single actor, it is easier to link them into one group. This can be justified by the fact that all those groups are concerned in 1) political stability within the federal unit and 2) their own influence in the region. The federal elites retained the belligerent parties from armed conflict in the early 1990s in order to prevent the Chechen scenario in other republics. After the recentralization reforms and authoritarian consolidation, the national authorities re-established a full control over the regional governments and demanded the necessary electoral results for incumbent parties, instead providing them with budgetary funds. Interestingly, regional rulers afforded to conduct informal negotiations with influential federal players in order to tackle their competitors. Electoral results have been a mere outward manifestation of bargains between parties.

Finally, I want to take a brief look at the procedures applied by the key actors to achieve their goals and impose the state of political stability, i.e. to protect their positions and stay in power. Our first hypothesis stated that ruling coalitions in regions with ethnic-based societal cleavages resort to ethnic power-sharing as a means to cope with influential ethnic social movements and tranquillize their protest capacities. Co-optation of public leaders into the ruling class by providing them access to rent and state resources may successfully pacify the tumultuous political environment. Thus, ballot-rigging in limited access orders is another way to redistribute dominions and privileges. Given the consequences of Balkar social movement's activity in the 1990s, we can even suggest that ethnic quota has the potential to be used as a justification for electoral fraud.

According to the second hypothesis, the informal plea bargain between politicians is an essential attribute of limited access orders, especially in subnational units of federation, regulating membership of the upper class. KBR as a part of Russian Federation vividly exemplifies this correlation. The regional political elites are free to govern in their respective territory and enjoy primary access to the benefits and privileges, at the forefront subsidies from the federal budget (which makes 
elections different in the national and sub-national limited access orders). In return, they are obliged to satisfy inquiries from the supreme level. In terms of elections, this means reaching high figures of voting results: turnout and support for incumbent. But this pattern is a two-way street: local politicians are able to use this situation to regulate the popular perceptions of falsifications and to advocate the legitimacy of rigged elections, claiming their necessity for the sake of the region, its prosperity and good economic performance.

The power struggle between regional parties may also be affected by intervention from the federal level. Regional incumbents may appeal to the central authorities to champion them in their struggles with the local contesters. The use of formal rules in these situations is backed by hidden agreements, and those "nested games" become a part of the hybrid-oriented institutional environment.

Beyond that, once we turn a blind eye to the impeding effect of ethnic quota for future democratization (although the North's framework has nothing to do with democratization), we can assume that this informal institution creates a win-win situation for all participants of the game, namely the federal elite, the subnational governing groups, and the social movements, especially given the absence of the potential challengers. In fact, the absence of challengers is not the state of affairs; the logic of limited access orders is that political contesters are restricted by the established formal and informal rules. Put another way, the possible challengers have to take into consideration the existing institutional framework and to follow the rules that are (mostly) in favour of the ruling coalition, therefore complicating and hampering the newcomers' path to power, rent, and resources (although this allegation shall not be considered res judicata).

\section{BIBLIOGRAPHY}

Адиев и др. 2017 - Адиев А.З., Аккиева С.И., Щербина Е.А. Этничность и распределение властных позиций в Кабардино-Балкарии и Карачаево-Черкесии в ракурсе экспертных мнений // Гуманитарные и социально-политические проблемы модернизации Северного Кавказа. - Магас: ИГУ, 2017. - С. 8-19.

Боров 2016 - Боров А.Х. Кабардино-Балкария на выборах 1990-х: поиск стабильности в нестабильной политической среде // Известия Кабардино-Балкарского научного центра PAH. - 2016. - № 5 (73). - C. 155-170.

Боров и др. 1999 - Боров А.Х., Думанов Х.М., Кажаров В.Х. Современная государственность Кабадино-Балкарии: истоки, пути становления, проблемы. - Нальчик: Эль-Фа, 1999. - 183 с.

Гельман 2010 - Гельман В.Я. «Подрывные» институты и неформальное управление в современной России // Полития: Анализ. Хроника. Прогноз (Журнал политической философии и социологии политики). - 2010. - № 2 (57). - С. 6-24.

Гельман 2006 - Гельман В.Я. Выборы по-русски: правила игры в российской электоральной политике // Россия и современный мир. - 2006. - №2 (56). - С. 54-67.

Гельман 2003 - Гельман В.Я. Институциональное строительство и неформальные институты в современной российской политике // Полис. Политические исследования. 2003. - № 4. - C. 6-25.

Гельман 2005 - Гельман В.Я. Эволюция электоральной политики в России: на пути к недемократической консолидации? // Политическая наука. - 2005. - № 2. - С. 8-25.

Казенин 2009 - Казенин К.И. «Тихие конфликты» на Северном Кавказе. Адыгея, Кабардино-Балкария, Карачаево-Черкесия. - M.: REGNUM, 2009. - 180 с. 
Казенин 2010 - Казенин К.И. Кабардино-Балкарская республика // Республики Северного Кавказа: этнополитическая ситуация и отношения с федеральным Центром: Монография / Научный редактор и составитель И.Г. Косиков. - М.: МАКС Пресс, 2012. - С. 183-212.

Кокорхоева 2012 - Кокорхоева Д.С. Политическая институционализация органов государственной власти субъектов Российской Федерации (на материалах республик). Автореф... д. полит. н. - Краснодар, 2012. - 47 с.

Кынев 2009 - Кынев А.В. Выборы парламентов российских регионов 2003-2009 гг.: первый цикл внедрения пропорциональной избирательной системы. - М.: Центр «Панорама», 2009. - 516 c.

Литвинова 2011 - Литвинова T.Н. Политические институты на Северном Кавказе в контексте развития российской государственности. - Саарбрюккен: LAP LAMBERT Academic Publishing, 2011. - 292 c.

Мельвиль 2004 - Мельвиль А.Ю. О траекториях посткоммунистических трансформаций // Полис. Политические исследования. - 2004. - № 2. - С. 64-75.

Панов 2004 - Панов П.В. Изменение электоральных институтов в России. Кроссрегиональный сравнительный анализ // Полис. Политические исследования. - 2004. № 6. - С. 16-28.

Панов 2006 - Панов П.В. Региональные политические процессы в РФ в «эпоху Путина»: унификация или диверсификация? // Политическая экспертиза: ПОЛИТЭКС. 2006. - T. 2. - № 4. - C. 86-103. URL: http://www.politex.info/content/view/300/2/ (дата обращения: 05.08.2018)

Силаев 2015 - Силаев Н.Ю. О фрагментации государства, эволюции этнических движений и сепаратизме в России // Сепаратизм в политической жизни современной Европы / Под ред. П.Е. Канделя. - М.: Ин-т Европы РАН, 2015. - С. 23-42.

Стародубровская, Казенин 2016 - Стародубровская И.В, Казенин К.И. Северный Кавказ и современная модель демократического развития. Экспертный доклад. 01 апреля 2016 // Комитет гражданских инициатив. [Электронный pecypc]. URL: https://komitetgi.ru/analytics/2774/ (дата обращения: 05.08.2018).

Такова 2010 - Такова A.H. К вопросу об истоках и динамике политизации этничности в Кабардино-Балкарии во второй половине 80-х гг. XX в. - начале XXI в. // Исторический вестник. - 2010. - IX вып. - С. 91-108.

Тумов 2017 - Тумов А.А. Избирательный процесс в современной Кабардино-Балкарии: эволюция политических условий, устойчивость политических результатов // Электронный журнал - Кавказология. - 2017. - №2. - C. 119-139. DOI: https://doi.org/10.31143/2542-212X2017-2-119-139

Шорова 2010 - Шорова М.Б. Национальный вопрос в общественно-политической жизни Кабардино-Балкарии (середина 1980-х - 1990-е гг.). Дисс. ... канд. ист. наук. Нальчик, 2010. - 206 с.

Шхагапсоев и др. 2011 - Шхагапсоев 3.Л., Тенгизова Ж.А., Урумов А.В., Хамуков А.В. Конституционная реформа в Кабардино-Балкарской Республике. - Нальчик: Нальчикский филиал Краснодарского университета МВД России, 2011. - 407 с.

Щербак 2010 - Щербак А.Н. «Нефтяное проклятие» политического развития // Нефть,

газ, модернизация общества. - СПб.: Экономическая школа, 2010. URL: seinstitute.ru/Files/Oil-2p31-52.pdf (дата обращения: 07.07.2018).

Aliyev 2015 - Aliyev H. Post-Soviet Informality: towards Theory-Building // International Journal of Sociology and Social Policy. - 2015. - Vol. 35. - No. 3/4. - P. 182-198.

Belokurova 2018 - Belokurova G. Soviet Legacies, Organized Crime, and Economic Gangsterism: Russia, 1995-2010 // Communist and Post-Communist Studies. - 2018 - Vol. 51. No. 1. - P. 1-17. 
Blaydes 2011 - Blaydes L. Elections and Distributive Politics in Mubarak' Egypt. Cambridge, UK: Cambridge University Press, 2011. - 275 p.

Boege et al. 2009 - Boege V., Brown M.A., Clements K.P. Hybrid Political Orders, Not Fragile States // Peace Review. - 2009. - Vol. 21. - No. 1. - P. 13-21.

Carothers 2002 - Carothers Th. The End of the Transition Paradigm // Journal of Democracy. - 2002. - Vol. 13. - No. 1. - P. 5-21.

Cassani 2014 - Cassani A. Hybrid What? Partial Consensus and Persistent Divergences in the Analysis of Hybrid Regimes // International Political Science Review. - 2014. - Vol. 35. - No. 5. - P. 542-558.

Collier 2009 - Collier P. Wars, Guns and Votes: Democracy in Dangerous Places. - New York: Harper Collins, 2009. - 260 p.

Dahl 2000 - Dahl R. On Democracy. - New-Haven: Yale University Press, 2000. - 272 p.

Diamond 2002 - Diamond L. Thinking About Hybrid Regimes // Journal of Democracy. 2002. - Vol. 13. - No. 2. P. 21-35.

Dowding 1983 - Dowding K. The Meaning and Use of «Political Stability» // European Journal of Political Research. - 1983. - No. 11. - P. 229-243.

Ekman 2009 - Ekman J. Political Participation and Regime Stability: A Framework for Analyzing Hybrid Regimes // International Political Science Review. - 2009. - Vol. 30. - No. 1. P. 7-31.

Elklitt, Svensson 1997 - Elklitt J., Svensson P. What Makes Elections Free and Fair? // Journal of Democracy. - 1997. - Vol. 8. - No. 3. P. 32-46.

Elwert 2003 - Elwert G. Intervention in Markets of Violence / Potentials of Disorder, ed. Jan Koehler and Kristof Zürcher. - Manchester: Manchester University Press, 2003. - P. 219-242.

Gandhi 2008 - Gandhi J. Political Institutions under Dictatorship. - New York: Cambridge University Press, 2008. - $232 \mathrm{p}$.

Gandhi, Lust 2006 - Gandhi J., Lust E. Elections under Authoritarianism // Annual Review of Political Science. - 2006. - Vol. 12. - No. 1. P. 403-422.

Gasiorowski 2006 - Gasiorowski M. The Political Regimes Project // On Measuring Democracy: Its Consequences and Concomitants / Ed. Alex Inketes. - New Brunswick and London, 2006. https://books.google.de/books?id=uxO2QHFzlZsC\&pg=PA105\&redir_esc=y\#v=onepage\&q\&f=fal se (last accessed: 05.08.2018).

Geddes 1995 - Geddes B. A Comparative Perspective on the Leninist Legacy in Eastern Europe // Comparative Political Studies. - 1995. - Vol. 28. - No. 2. - P. 239-274.

Gelman 2002 - Gelman V. Russia's Elites in Search of Consensus: What Kind of Consolidation? // Demokratizatsya. The Journal of Post-Soviet Democratization. - 2002. - Vol. 10. - No. 3. - P. 343-361.

Gibson 2005 - Gibson E. Boundary Control: Subnational Auhtoritarianism in Democratic Countries // World Politics. - 2005. - Vol. 58. - No. 1. - P. 101-132.

Golosov 2016 - Golosov G. Why and How Electoral Systems Matter in Autocracies // Australian Journal of Political Science. - 2016. - Vol. 51. - No. 3. - P. 367-385.

Goodhand, Sedra 2013 - Goodhand J., Sedra M. Rethinking Liberal Peacebuilding, Statebuilding and Transition in Afghanistan: An Introduction // Central Asian Survey. - 2013. Vol. 32. - No. 3. - P. 239-254.

Hinnenbusch 2010 - Hinnebusch R. Towards a Historical Sociology of State Formation in the Middle East // Middle East Critique. - 2010. - Vol. 19. - No. 3. - P. 201-216.

Koehler, Zürcher 2003 - Koehler J., Zürcher K. Institutions and the Organization of Stability and Violence // Potentials of Disorder / Ed. by J. Koehler, K. Zürcher. - Manchester: Manchester University Press, 2003. - P. 243-266.

Lauth 2000 - Lauth H. Informal Institutions and Democracy // Democratization. - 2000. Vol. 7. - No. 4. - P. 21-50. 
Levitsky 2002 - Levitsky S., Way L. Elections Without Democracy. The Rise of Competitive Authoritarianism // Journal of Democracy. - 2002. - Vol. 13. - No. 2. - P. 51-65.

Miller 2006 - Miller S. Ethnic Conflict, Electoral Systems, and Power Sharing in Divided

Societies. PhD diss. - Georgia State University, 2006. - Retrieved from https://scholarworks.gsu.edu/political_science theses/7/ (last accessed: 05.08.2018).

North 1990 - North D. Institutions, Institutional Change and Economic Performance. New-York: Cambridge University Press, 1990. - 159 p.

North et al. 2009 - North D., Wallis J., Weingast B. Violence and Social Orders: A Conceptual Framework for Interpreting Recorded Human History. - New-York: Cambridge University Press, 2009. - 346 p.

Olsson 2016 - Olsson J. Subversion in Institutional Change and Stability: A Neglected Mechanism. - London: Palgrave Macmillan, 2016. - 120 p.

Panov 2016 - Panov P. In Search of Inter-Ethnic Balance: Ethnic Composition and Informal Power-sharing in Russian National Republics // European Politics and Society. - 2016. - Vol. 17. No. 3. - P. 353-372.

Panov, Ross 2013 - Panov P., Ross C. Patterns of Electoral Contestation in Russian Regional Assemblies: Between "Competitive" and "Hegemonic" Authoritarianism // Demokratizatsya. The Journal of Post-Soviet Democratization. - 2013. - Vol. 21. - No. 3. - P. 369400.

Riese et al. 2010 - Riese S., Roehner N., Zuercher C. External Strategies for Post-Conflict Democratization: Bosnia and Herzegovina, Kosovo, and Macedonia // Yearbook on the Organization for Security and Co-operation in Europe (OSCE). - 2010. - P. 265-281.

Ross 2002 - Ross C. Federalism and Democratization in Russia. - Manchester: Manchester University Press, 2002. - 182 p.

Schedler 2006 - Schedler A. The Logic of Electoral Authoritarianism / Electoral Authoritarianism: The Dynamics of Unfree Competition, ed. Andreas Schedler. - Boulder, Lynne Rienner Publishers, 2006. - P. 1-26.

Schedler 2002 - Schedler A. The Nested Game of Democratization by Elections // International Political Science Review. - 2002. - Vol. 23 - No. 1. - P. 103-122.

Snyder 2000 - Snyder J. From Voting to Violence. Democratisation and Nationalist Conflict. - New York: W.W. Norton, 2000. - 320 p.

Svolik 2012 - Svolik M. The Politics of Authoritarian Rule. - Cambridge: Cambridge Univ. Press, 2012. $-258 \mathrm{p}$.

The Politics... 2010 - The Politics of Sub-National Authoritarianism in Russia. Ed. Vladimir Gel'man and Cameron Ross. Post-Soviet Politics. - Burlington, Vt.: Ashgate, 2010. xviii, 229 p.

Way 2006 - Way L. Authoritarian Failure: How Does State Weakness Strengthen Electoral Competition // Electoral Authoritarianism: The Dynamics of Unfree Competition / Ed. Andreas Schedler. - Boulder, Lynne Rienner Publishers, 2006. - P. 167-180.

White 1985 - White S. Non-competitive Elections and National Politics: The USSR Supreme Soviet Elections of 1984 // Electoral Studies. - 1985. - Vol. 4. - No. 3. - P. 215-229.

\section{REFERENCES}

ADIYEV A.Z., AKKIYEVA S.I., SHCHERBINA E.A. Etnichnost' $i$ raspredeleniye vlastnykh pozitsiy $v$ Kabardino-Balkarii $i$ Karachayevo-Cherkesii $v$ rakurse ekspertnykh mneniy [Ethnicity and power-sharing in Kabardino-Balkaria and Karachay-Cherkessia: expert opinions] // Gumanitarnyye $i$ sotsial'no-politicheskiye problemy modernizatsii Severnogo Kavkaza [Humanitarian and socio-political problems of the modernization of the North Caucasus]. - Magas: IGU, 2017. - P. 8-19. (In Russian) 
ALIYEV H. Post-Soviet Informality: towards Theory-Building // International Journal of Sociology and Social Policy. - 2015. - Vol. 35. - No. 3/4. - P. 182-198.

BELOKUROVA G. Soviet Legacies, Organized Crime, and Economic Gangsterism: Russia, 1995-2010 // Communist and Post-Communist Studies. - 2018 - Vol. 51. - No. 1. - P. 1-17.

BLAYDES L. Elections and Distributive Politics in Mubarak' Egypt. - Cambridge, UK: Cambridge University Press, 2011. - 275 p.

BOEGE V., BROWN M.A., CLEMENTS K.P. Hybrid Political Orders, Not Fragile States // Peace Review. - 2009. - Vol. 21. - No. 1. - P. 13-21.

BOROV A.Kh. Kabardino-Balkariya na vyborakh 1990-kh: poisk stabil'nosti v nestabil'noy politicheskoy srede [Kabardino-Balkaria in the elections of 1990s: searching stability amidst unstable political environment] // Izvestiya Kabardino-Balkarskogo nauchnogo tsentra RAN. 2016. - No. 5 (73). - P. 155-170. (In Russian)

BOROV A.Kh., DUMANOV Kh.M., KAZHAROV V.Kh. Sovremennaya gosudarstvennost' Kabadino-Balkarii: istoki, puti stanovleniya, problem [The Modern Statehood of the KabardinBalkar Republic: origins, emergence, problems]. - Nal'chik: El'-Fa, 1999. - 183 p. (In Russian)

CAROTHERS Th. The End of the Transition Paradigm // Journal of Democracy. - 2002. Vol. 13. - No. 1. - P. 5-21.

CASSANI A. Hybrid What? Partial Consensus and Persistent Divergences in the Analysis of Hybrid Regimes // International Political Science Review. - 2014. - Vol. 35. - No. 5. - P. 542558.

COLLIER P. Wars, Guns and Votes: Democracy in Dangerous Places. - New York: Harper Collins, 2009. $-260 \mathrm{p}$.

DAHL R. On Democracy. - New-Haven: Yale University Press, 2000. - 272 p.

DIAMOND L. Thinking About Hybrid Regimes // Journal of Democracy. - 2002. - Vol. 13. - No. 2. P. 21-35.

DOWDING K. The Meaning and Use of "Political Stability" // European Journal of Political Research. - 1983. - No. 11. - P. 229-243.

EKMAN J. Political Participation and Regime Stability: A Framework for Analyzing Hybrid Regimes // International Political Science Review. - 2009. - Vol. 30. - No. 1. P. 7-31.

ELKLITT J., SVENSSON P. What Makes Elections Free and Fair? // Journal of Democracy. - 1997. - Vol. 8. - No. 3. P. 32-46.

ELWERT G. Intervention in Markets of Violence // Potentials of Disorder / Ed. by J. Koehler, K. Zürcher. - Manchester: Manchester University Press, 2003. - P. 219-242.

GANDHI J. Political Institutions under Dictatorship. - New York: Cambridge University Press, 2008. - $232 \mathrm{p}$.

GANDHI J., LUST E. Elections under Authoritarianism // Annual Review of Political Science. - 2006. - Vol. 12. - No. 1. P. 403-422.

GASIOROWSKI M. The Political Regimes Project // On Measuring Democracy: Its Consequences and Concomitants / Ed. Alex Inketes. - New Brunswick and London, 2006. - P. 105122.

https://books.google.de/books?id=uxO2QHFzlZsC\&pg=PA105\&redir_esc=y\#v=onepage\&q\&f=fal se (last accessed: 05.08.2018).

GEDDES B. A Comparative Perspective on the Leninist Legacy in Eastern Europe // Comparative Political Studies. - 1995. - Vol. 28. - No. 2. - P. 239-274.

GEL'MAN V.Y. "Podryvnyye» instituty i neformal'noye upravleniye v sovremennoy Rossii [Subversive Institutions and Informal Governance in Contemporary Russia] // Politiya: Analaziz. Khronika. Prognoz (Zhurnal politicheskoy filosofii i sotsiologii politiki). - 2010. - No.2 (57). - P. 6-24. (In Russian)

GEL'MAN V.Y. Evolyutsiya elektoral'noy politiki v Rossii: na puti $k$ nedemokraticheskoy konsolidatsii? [Evolution of Russian Electoral Politics: Towards Non-Democratic Consolidation?] // Politicheskaya nauka. - 2005. - No. 2. - P. 8-25. (In Russian) 
GEL'MAN V.Y. Institutsional'noye stroitel'stvo i neformal'nyye instituty $v$ sovremennoy rossiyskoy politike [Institution-building and Informal Institutions in Russian Politics] // Polis. Politicheskiye issledovaniya. - 2003. - No. 4. - P. 6-25. (In Russian)

GEL'MAN V.Y. Vybory po-russki: pravila igry v rossiyskoy elektoral'noy politike [Russian Elections: The Rules of Game in Russian Electoral Politics] // Rossiya i sovremennyy mir. - 2006. - No. 2 (56). - P. 54-67. (In Russian)

GELMAN V. Russia's Elites in Search of Consensus: What Kind of Consolidation? // Demokratizatsya. The Journal of Post-Soviet Democratization. - 2002. - Vol. 10. - No. 3. - P. 343361.

GIBSON E. Boundary Control: Subnational Auhtoritarianism in Democratic Countries // World Politics. - 2005. - Vol. 58. - No. 1. - P. 101-132.

GOLOSOV G. Why and How Electoral Systems Matter in Autocracies // Australian Journal of Political Science. - 2016. - Vol. 51. - No. 3. - P. 367-385.

GOODHAND J., SEDRA M. Rethinking Liberal Peacebuilding, Statebuilding and Transition in Afghanistan: An Introduction // Central Asian Survey. - 2013. - Vol. 32. - No. 3. - P. 239-254.

HINNEBUSCH R. Towards a Historical Sociology of State Formation in the Middle East // Middle East Critique. - 2010. - Vol. 19. - No. 3. - P. 201-216.

KAZENIN K.I. "Tikhiye konflikty» na Severnom Kavkaze. Adygeya, Kabardino-Balkariya, Karachayevo-Cherkesiya [Silent Conflicts" in the North Caucasus: Adygea, Karachay-Cherkessia, Kabardino-Balkaria]. - M.: REGNUM, 2009. - 180 p. (In Russian)

KAZENIN K.I. Kabardino-Balkarskaya respublika [Kabardin-Balkar republic] // Respubliki Severnogo Kavkaza: etnopoliticheskaya situatsiya $i$ otnosheniya $s$ federal'nym Tsentrom: Monografiya [The North Caucasian Republics: Ethnopolitical situation and Federal-Province Relations] / Ed. by I.G. Kosikov. - M.: MAKS Press, 2012. - P. 183-212. (In Russian)

KOEHLER J., ZÜRCHER K. Institutions and the Organization of Stability and Violence // Potentials of Disorder / Ed. by Jan Koehler and Kristof Zürcher. - Manchester: Manchester University Press, 2003. - P. 243-266.

KOKORKHOYEVA D.S. Politicheskaya institutsionalizatsiya organov gosudarstvennoy vlasti sub"yektov Rossiyskoy Federatsii (na materialakh respublik) [Political Institutionalisation of Public Authorities in Constituent Entities of Russian Federation]. Abstract of the thesis for a Doctor of polit. sciences degree. - Krasnodar, 2012. - 47 p. (In Russian)

KYNEV A.V. Vybory parlamentov rossiyskikh regionov 2003-2009 gg.: pervyy tsikl vnedreniya proportsional'noy izbiratel'noy sistemy [The 2003-2009 Legislative Elections in Russian Regions: The First Round of Implementing the Proportional Representation System]. - M.: Tsentr «Panorama», 2009. - 516 p. (In Russian)

LAUTH H. Informal Institutions and Democracy // Democratization. - 2000. - Vol. 7. - No. 4. - P. 21-50.

LEVITSKY S., WAY L. Elections Without Democracy. The Rise of Competitive Authoritarianism // Journal of Democracy. - 2002. - Vol. 13. - No. 2. - P. 51-65.

LITVINOVA T.N. Politicheskiye instituty na Severnom Kavkaze $v$ kontekste razvitiya rossiyskoy gosudarstvennosti [Political Institutions in the North Caucasus in the Context of Development of Russian Statehood]. - Saarbryukken: LAP LAMBERT Academic Publishing, 2011. - 292 s. (In Russian)

MELVIL' A.Y. O trayektoriyakh postkommunisticheskikh transformatsiy [On Trajectories of Post-Communist Transformations] // Polis. Politicheskiye issledovaniya. - 2004. - No. 2. - P. 6475. (In Russian)

MILLER S. Ethnic Conflict, Electoral Systems, and Power Sharing in Divided Societies. $\mathrm{PhD}$ diss. - Georgia State University, 2006. - Retrieved from https://scholarworks.gsu.edu/political_science theses/7/ (last accessed:05.08.2018).

NORTH D. Institutions, Institutional Change and Economic Performance. - New-York: Cambridge University Press, 1990. - 159 p. 
NORTH D., WALLIS J., WEINGAST B. Violence and Social Orders: A Conceptual Framework for Interpreting Recorded Human History. - New-York: Cambridge University Press, 2009. - $346 \mathrm{p}$.

OLSSON J. Subversion in Institutional Change and Stability: A Neglected Mechanism. London: Palgrave Macmillan, 2016. - 120 p.

PANOV P. In Search of Inter-Ethnic Balance: Ethnic Composition and Informal Powersharing in Russian National Republics // European Politics and Society. - 2016. - Vol. 17. - No. 3. - P. 353-372.

PANOV P., ROSS C. Patterns of Electoral Contestation in Russian Regional Assemblies: Between "Competitive" and "Hegemonic" Authoritarianism // Demokratizatsya. The Journal of Post-Soviet Democratization. - 2013. - Vol. 21. - No. 3. - P. 369-400.

PANOV P.V. Izmeneniye elektoral'nykh institutov v Rossii. Krossregional'nyy sravnitel'nyy analiz [Alteration of Electoral Institutions in Russia (Cross-Regional Analysis)] // Polis. Politicheskiye issledovaniya. - 2004. - No. 6. - P. 16-28. (In Russian)

PANOV P.V. Regional'nyye politicheskiye protsessy v RF v «epokhu Putina»: unifikatsiya ili diversifikatsiya? [Regional Political Processes in Russia of "Putin Era": Unification or Diversification?] // Politicheskaya ekspertiza: POLITEKS. - 2006. - Vol. 2. - No.4. - P. 86-103. URL: http://www.politex.info/content/view/300/2/ (date of access: 05.08.2018) (In Russian)

RIESE S., ROEHNER N., ZUERCHER C. External Strategies for Post-Conflict Democratization: Bosnia and Herzegovina, Kosovo, and Macedonia // Yearbook on the Organization for Security and Co-operation in Europe (OSCE). - 2010. - P. 265-283.

ROSS C. Federalism and Democratization in Russia. - Manchester: Manchester University Press, 2002. - $182 \mathrm{p}$.

SCHEDLER A. The Logic of Electoral Authoritarianism // Electoral Authoritarianism: The Dynamics of Unfree Competition / Ed. Andreas Schedler. - Boulder, Lynne Rienner Publishers, 2006. - P. 1-26.

SCHEDLER A. The Nested Game of Democratization by Elections // International Political Science Review. - 2002. - Vol. 23 - No. 1. - P. 103-122.

SHCHERBAK A.N. "Neftyanoye proklyatiye» politicheskogo razvitiya [Resource Curce of Federal Development] // Oil, gas, modernization of society. - SPb .: Economic School, 2010. URL: seinstitute.ru/Files/Oil-2p31-52.pdf (date of access: 07.07.2018). (In Russian)

SHKHAGAPSOYEV Z.L., TENGIZOVA Zh.A., URUMOV A.V., KHAMUKOV A.V. Konstitutsionnaya reforma v Kabardino-Balkarskoy Respublike [The Constitutional Reform in the Kabardino-Balkarian Republic]. - Nal'chik: Nal'chikskiy filial Krasnodarskogo universiteta MVD Rossii, 2011. - 407 p.

SHOROVA M.B. Natsional'nyy vopros v obshchestvenno-politicheskoy zhizni KabardinoBalkarii (seredina 1980-kh - 1990-ye gg.) [The National Issue in Socio-Political Life in KabardinoBalkaria (mid 1980s - 1990s)]. The dissertation for the Candidate of historical sciences degree. Nal'chik, 2010. - 206 p. (In Russian)

Silayev N.Y. O fragmentatsii gosudarstva, evolyutsii etnicheskikh dvizheniy i separatizme v Rossii [State Fragmentation, Ethnic Movements' Evolution, and Separatism in Russia] // Separatizm v politicheskoy zhizni sovremennoy Yevropy / pod red. P.Ye. Kandelya. - M.: In-t Yevropy RAN, 2015. - S. 23-42. (In Russian)

SNYDER J. From Voting to Violence. Democratisation and Nationalist Conflict. - New York: W.W. Norton, 2000. -320 p.

STARODUBROVSKAYA I.V, KAZENIN K.I. Severnyy Kavkaz i sovremennaya model' demokraticheskogo razvitiya. Ekspertnyy doklad [The North Caucasus and the Contemporary Pattern of Democratic Development] // Komitet grazhdanskikh initsiativ [Civil Initiatives Committee]. URL: https://komitetgi.ru/analytics/2774/ (date of access: 05.08.2018). (In Russian)

SVOLIK M. The Politics of Authoritarian Rule. - Cambridge: Cambridge Univ. Press, 2012. - 258 p. 
TAKOVA A.N. $K$ voprosu ob istokakh $i$ dinamike politizatsii etnichnosti $v$ KabardinoBalkarii vo vtoroy polovine 80-kh gg. KHKH v. - nachale XXI v. [The Origins and Dynamics of Politicizing Ethnicity in Kabardino-Balkaria in the late 1980s - the early 2000s] // Istoricheskiy vestnik. - 2010. - IX issue. - P. 91-108. (In Russian)

The Politics of Sub-National Authoritarianism in Russia / Ed. Vladimir Gel'man and Cameron Ross. Post-Soviet Politics. - Burlington, Vt.: Ashgate, 2010. - xviii, 229 p.

TUMOV A.A. Izbiratel'nyy protsess v sovremennoy Kabardino-Balkarii: evolyutsiya politicheskikh usloviy, ustoychivost' politicheskikh rezul'tatov [Electoral Process in Modern Kabardino-Balkaria: Evolution of Political Situation, Stability of Political Results] // Kavkazologiya [Caucasology]. - 2017. - No. 2. - P. 119-139. DOI: https://doi.org/10.31143/2542-212X-2017-2119-139 (In Russian)

WAY L. Authoritarian Failure: How Does State Weakness Strengthen Electoral Competition // Electoral Authoritarianism: The Dynamics of Unfree Competition / Ed. Andreas Schedler. - Boulder, Lynne Rienner Publishers, 2006. - P. 167-180.

WHITE S. Non-competitive Elections and National Politics: The USSR Supreme Soviet Elections of 1984 // Electoral Studies. - 1985. - Vol. 4. - No. 3. - P. 215-229. 